\title{
Problems and Prospects of Cashew Cultivation in India - An Overview
}

\author{
H.R. Bhoomika* and N. Sudha Rani \\ College of Horticulture, Mudigere, Chickmagalur (D), Karnataka -577 132, India \\ *Corresponding author
}

\begin{abstract}
A B S T R A C T
Keywords

Cashew, Industry,

Processing,

Problem, Scope

\section{Article Info}

Accepted:

25 September 2018

Available Online:

10 October 2018

Cashew, a perennial tree well known as 'poor man's crop' is a source of highly priced cashew nuts. India being the leading producer, consumer and second largest exporter of cashew in the world, has a prime position in cashew trade in the world market. But the productivity level of Indian cashew is far less than that of its close competitors viz., Vietnam, Nigeria, Cote de'Ivoire, Philippines etc. The cashew processing sector in India is one of the largest in the world and has given huge employment to rural people especially the women folk. Some of the cashews processing industries in India are still under unorganized sector. Increasing demand for the nuts has necessitated the increased production. The present review is an attempt made towards understanding the Indian cashew industry in relation to its position in the global market, problems being faced by the cashew industry and the scope in future.
\end{abstract}

\section{Introduction}

Cashew (Anacardium occidentale L.) a native of Brazil has acclimatized and adapted well to Indian climate and praised the world over for its delicious and nutritious kernels. Being introduced by the Portuguese sailors to the Malabar coast during $16^{\text {th }}$ century it has travelled a long way to earn the status of 'a Dollar earning crop' from a mere 'Crop of waste lands'.

Cashew is a tropical, evergreen, perennial tree with a darkish-green leathery foliage, spreading branches and very irregular crown. The flowers are borne in a panicle that consists of three types of flowers name hermaphrodite (bisexual), male and sterile flowers. Actual fruit is the nut and apple is rather a pseudo fruit which is nothing but a swollen receptacle. The colour and shape of the apple varies with cultivars ranging from yellow, greenish yellow to red. Apple weighs about ten times more than that of nut and the nut weight usually ranges from 3 to $15 \mathrm{~g}$.

Cashew being tropical crop can tolerate higher temperatures but is highly sensitive to frost. The optimum temperature range for successful cultivation is about 20 to $30^{\circ} \mathrm{C}$. The annual precipitation of 1000 to $2000 \mathrm{~mm}$ is ideal for cashew. Coincidence of flowering with high rain fall or excess humidity leads to incidence of pests and diseases. Though cashew is not 
very exacting in its soil requirements and come up well even in poor soils, the yield performance is better in well drained, fertile soils. Clayey soils with poor drainage and soils with $\mathrm{pH}$ more than 8 are unsuitable for the crop. Red sandy loam, lateritic soils with slightly acidic to neutral $\mathrm{pH}$ are best suited for cashew cultivation.

\section{Chemical composition and uses of cashew}

The nut is composed of outer shell and the kernel inside. The cashew shell contains $25 \%$ of this reddish brown oil, industrially known as Cashew Nut Shell Liquid (CNSL) which is a by-product of the roasting process. Santos Andrade et al. (2011) have suggested the possible use of CNSL in nutraceutical and pharmaceutical industries owing to its high antioxidant activity.

Cashew nuts are not only delicious but also nutritious. Nuts are regarded a store house of energy and have played a major role in the human diet since ancient times. The overall composition of the kernel is protein $21 \%$, fat $46 \%$ and carbohydrates $25 \%$. The table 1 depicts the nutritional composition of raw cashew kernels per $100 \mathrm{~g}$ weight.

Among the fatty acids oleic acid belonging to MUFA (Mono Unsaturated Fatty Acids) group is the most abundant, contributing $60.70 \%$ to Total Fatty Acids followed by linoleic $(17.77 \%)$, palmitic (10.2\%), and stearic (8.93\%) acids.

The linoleic acid is extremely important for the development and maintenance of the nervous system and physiological function in humans (FAGUNDES, 2002). MUFAs and PUFAs (Poly Unsaturated Fatty Acids) are considered as healthy fatty acids which protect the heart health and hence considered as essential fatty acids in the diet.

\section{Materials and Methods}

Though the nuts are regarded to be the concentrated form of energy, the clinical studies have proven that there is no association between consumption of nuts and weight gain (Flores-Mateo et al., 2013). The benefits of the addition of nuts in a healthy diet in comparison of a low-fat diet have been reported by Estruch et al. (2013) wherein they reported $30 \%$ reduction in the incidence of major cardiovascular disorders and mortality in individuals consuming a Mediterranean diet supplemented with a handful of nuts a day, compared to those that are advised to consume a low-fat diet.

Mah et al. (2017) revealed the reduction in TC (Total Cholesterol and) by $3.9 \%$ and that of LDL by $2.3 \%$ upon consumption of cashew nuts (28-64g/day) in comparison with the control group fed with potato chips.

The delightful taste and the nutraceutical properties of the nut have made the cashew nut popular and luxury snacks item the world over.

\section{Origin and distribution}

Cashew is a native of Central and South America and has a Primary centre of origin in Amazonia and Secondary centre in Planalto of Brazil. Natural occurrence of cashew has been reported from Mexico to Peru, and in the West Indies. It was one of the first fruit trees from the New World to be widely distributed throughout the tropics by the early Portuguese and Spanish adventurers (Kapinga et al., 2010). The name cashew has derived from the Portuguese word 'caju', which in turn came from the Tupi-Indian word 'acaju' (Deckers et al., 2001).

Portuguese discovered cashew in Brazil, during 1578 and was introduced by them to 
Africa and India during the $16^{\text {th }}$ Century. The primary aim of its introduction was to conserve soil as they found cashew can prevent soil erosion through its strong root system and can come up well in waste lands. Use of cashew nuts and apples developed much later, and the international nut trade did not start until the 1920s (Rieger, 2006). It has slowly gained the commercial importance and is contributing a huge share to the economies of many of its growing countries like India, Sri Lanka, Thailand, Malay Peninsula, Philippines, Hawaii, Tahiti, Mauritius, Seychelles, Tanzania, Kenya, Madagaskar, Ivory Coast, Nigeria, Brazil, Vietnam etc.

\section{Area and production}

Portuguese have played a major role in introduction and distribution of cashew cultivation especially in Asia and Africa during $16^{\text {th }}$ and $17^{\text {th }}$ century. Asian and African countries together held the share of $53.4 \%$ and $41.4 \%$ of cashew production since past 2 decades and the rest $5.2 \%$ production comes from America.

India is the largest producer of Raw Cashew Nuts (RCN) however, Vietnam leads in cashew nut (kernel) production with a total production of 12.21 tonnes of nuts from 2.811 ha area. The production of cashew kernels in the world is showing an increasing trend from past three decades. The total world production of cashew was around 11.75 lakh tonnes during 1994 which rose to 48.98 lakh tonnes by 2016 (FAOSTAT, 2017).

Similarly the production of cashew nuts in India has also increased considerably during the years and the present production is about 7.79 lakh MT from an area of 10.40 lakh hectares. There has been considerable increase in the productivity of nuts also during the decades and the present productivity is 753 $\mathrm{kg} / \mathrm{ha}$ (Hubballi, 2018).
In India cashew cultivation is mainly confined to the peninsular region in the states viz., Kerala, Karnataka, Goa, Maharashtra, Tamil Nadu, Andhra Pradesh, Orissa and West Bengal. The cultivation of cashew has also extended to a limited extent to some non traditional regions like Chhattisgarh, Andaman and Nicobar Islands and North Eastern States of Assam, Manipur, Tripura, Meghalaya and Nagaland.

As the crop is having wider agro-climatic adaptability, there is still much scope for area expansion in non traditional areas and in waste lands. As per a joint survey report of ICAR (Indian Council of Agricultural Research) and NAAS (National Academy of Agricultural Sciences) there is about 100 million ha of degraded or waste land available in India (Anon., 2010). This includes eroded lands, chemically and physically degraded lands, mined and rocky terrains etc. Cashew being a hardy crop such degraded lands can be exploited for its area expansion though the yield levels are not comparable to that of arable lands.

\section{Present trade and future scope}

Vietnam is the world leader in export of cashew kernels, by having $62 \%$ share in the total exports followed by India, accounting for $21 \%$ total world exports. These countries also follow the same order with regard to cashew nut processing (Anon., 2018).

During 2016 India has imported cashew kernels worth 28.57 million US \$ which is far less compared to the value of the kernels exported during the period from India i.e. US \$ 730.99 million. India has imported cashew nuts (with shell) worth US \$ 1180 million whereas it exported the nuts worth US \$ 11.95 millions (FAOSTAT, 2017). These figures substantiate the huge potential of Indian cashew nut processing industries and at the 
same time indicate the requirement of raw nuts for further processing.

The major markets for Indian cashew kernel are USA, UAE, Netherlands, Germany, UK, Japan,Korea, France, Belgium etc. Over the last ten years export of cashew kernels from India slipped by $18 \%$. However the quantity of import of raw kernels increased markedly during the period. Increase in domestic consumption is one of the main reasons for declining export. The domestic consumption of cashew has increased from 58\% during 2006-07 to 80\% during 2016-17 (Jnanadevan, 2018).

Much of the supply of cashew comes from the small holdings and is the source of livelihood to the small farmers. All the members of a family and mainly the farm women play a major role in gathering of nuts and thereby earning daily revenue. There is a scope to encourage such small farmers for cultivation and setting up of small scale processing units collectively to empower them by creating employment opportunities.

\section{Processing and Value addition in cashew}

Cashew processing in India is run both at home scale as well as industry scale. The cashew industry provides employment to about 1.50 million people more than $90 \%$ of them are women. Much of the supply of raw nuts to the processing factories comes from small farmers. During 2010-11 India has imported 4.49 lakh tonnes of raw cashew kernels which rose to 7.27 lakh tonnes during 2016 -17 (FAOSTAT, 2017). The present processing capacity of Indian cashew processing industries is around 20 lakh tonnes which is far below the total production of the country. More than one third of the total processing need of the country is met by the imports. The crop loss in the major growing countries like Vietnam and Cambodia had a negative impact on Indian cashew industry as much of the raw nuts were diverted to those countries particularly from the African countries, creating a shortfall of raw nut supply during 2016-17 (Anon., 2017).

There are about 3940 cashew processing industries functioning in India, ranging from small to large scale, scattered all over the country. The major share is held by Maharashtra followed by Kerala (Hubballi, 2018). Much of these are semi mechanised and only few have full mechanization support.

The cashew kernels are graded based on size and colour. Table 2 depicts the commercial cashew grades in India. The bolder ones have high export value whereas the others have highest domestic demand. Not only the whole cashew nuts but the brokens also have export demand and India mainly exports it to European countries.

Brokens have highest demand from the house hold, bakery and the confectionary industries. The increasing demand from these sectors has solved the problem of disposal of brokens and pieces, the percentage of which is more in mechanically processed nuts.

Cashew apple, which otherwise go as waste can be employed for making hundreds of products. It is a rich source of vitamins, tannins and other mineral components. The vitamin $\mathrm{C}$ content is about five times more compared to that of citrus.

The table 2 depicts the nutritional composition of cashew apple. Blended juice, syrup, candy, jam, jelly, pickles, chocolates, confectioneries etc. are some of the products prepared from cashew apple. But the commercial exploitation of cashew apple is successfully been done only at Goa for making an alcoholic beverage "Feni". 
Table.1 Nutritive value of cashew kernel (per 100 g)

\begin{tabular}{|l|l|c|}
\hline SI. No. & \multicolumn{1}{|c|}{ Particulars } & Content (\%) \\
\hline 1 & Total Fat & 48.30 \\
\hline $\mathbf{2}$ & Unsaturated Fatty Acids & 79.70 \\
\hline 3 & Saturated Fatty Acids & 20.10 \\
\hline 4 & Trans Fatty Acids & 0.20 \\
\hline 5 & Proteins & 21.30 \\
\hline 6 & Carbohydrates & 20.50 \\
\hline 7 & Energy & $2525 \mathrm{~kJ}$ \\
\hline $\mathbf{8}$ & Vitamin & 5.80 \\
\hline $\mathbf{9}$ & Sodium & 0.014 \\
\hline 10 & Potassium & 0.062 \\
\hline 11 & Phosphorus & 0.052 \\
\hline 12 & Calcium & 0.004 \\
\hline
\end{tabular}

Source: Rico et al. (2016)

Table.2 The mean proximate composition of cashew apple juice $(\mathrm{mg} / 100 \mathrm{ml})$

\begin{tabular}{|l|l|}
\hline Phenols & 269.50 \\
\hline Condensed tannins & 266.00 \\
\hline Vitamin-C & 231.40 \\
\hline Sugars & 12.05 \\
\hline Potassium & 76.00 \\
\hline Calcium & 43.00 \\
\hline Magnesium & 10.92 \\
\hline Phosphorus & 0.79 \\
\hline Sodium & 0.41 \\
\hline
\end{tabular}

Source: Lowor and Agyente-Badu, 2009

Fig.1 Average production share of cashew snuts with shell by region (1994-2016)

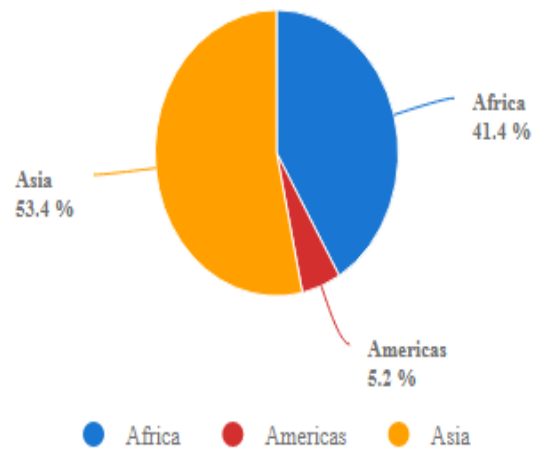

Source: FAOSTAT. 2017. 
Fig.2 World export of shelled cashew

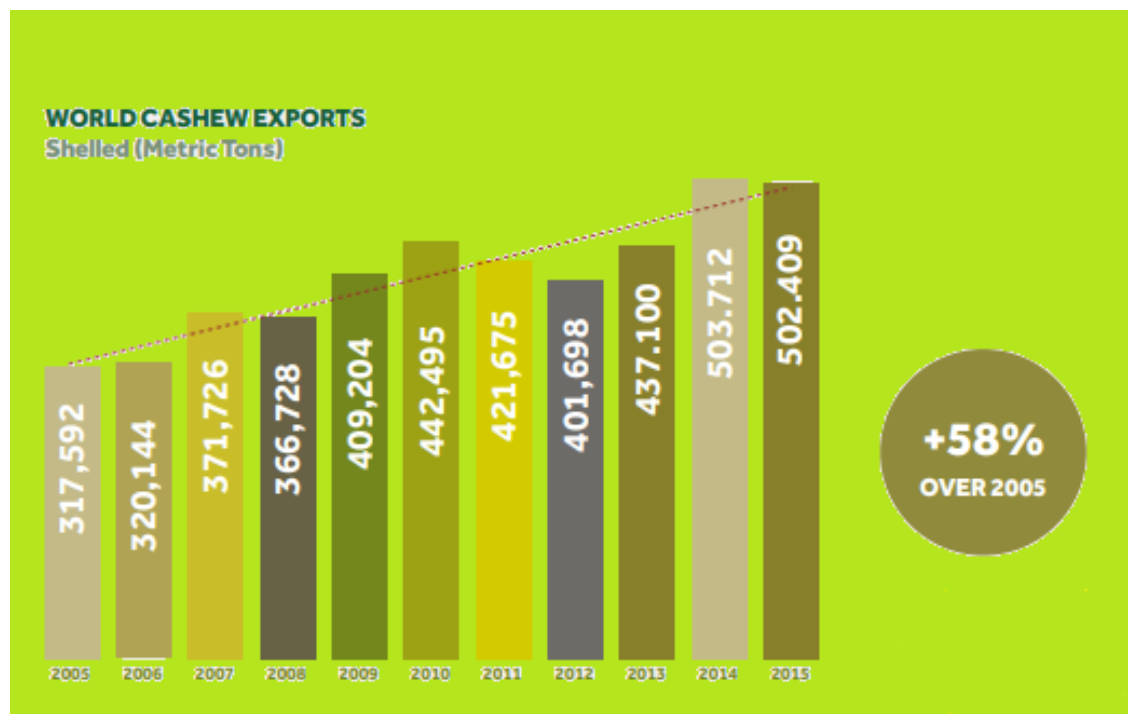

Source: INC International Nuts \& Dried Fruits Statistical Yearbook- 2016-17

\section{Constraints faced by the Indian cashew industry}

- The average productivity of the nuts in India is far less compared to that of other leading growers. This can be attributed to higher proportion of old and senile gardens in the country most of which have seedling origin. Due to heterozygosity the average performance of the orchards are poor.

- Much of the cashew growing area is in poor soil fertility zone, which has limited the crop from attaining its full yield potential.

- The fragmented land holdings have limitation in adapting the innovative technologies in cultivation of cashew.

- Much of the supply coming from small holders, processing is a difficult task.

- Higher initial investment cost for setting up the processing industry

- Non-availability of sufficient raw materials domestically and uneven supply of raw materials

- Fluctuating domestic prices and higher cost of imported raw nuts
- Non-availability of skilled manpower.

Prospects and future scope for Indian cashew

- India's in built strength lies in its diverse agro-climatic condition which is a boon to varied crop culture and so as for cultivation of cashew.

- Well defined and ever increasing domestic and world market for cashew and it's by products necessitates taking up cashew cultivation in a big way.

- The brand name of Indian cashew already created in the international market will pay added weightage to the products.

- Increasing purchase power of people has made this luxury food more accessible than before which has proven advantageous to increase the local as well the foreign demand for the nuts.

- Strong R\&D network throughout the country, capable of addressing newer issues evolving from time to time can boost up the production and productivity.

- Encouragement by the Government for area expansion by providing inputs and 
quality planting materials to the farmers is strengthening the cashew cultivation in India.

It is concluded that in this era of intensive agriculture and/ or horticulture, the small farmers are under much pressure of managing their production with the use of more and more inputs. The crops like cashew can be a boon to the farmers which can sustain with limited inputs and care, still earning higher revenue to the grower. With the consorted efforts of the Government and the private cashew industries much emphasis is being given on cultivation of cashew the benefit can be availed by the farmers to improve their livelihood and in turn contributing to national economy.

\section{References}

Anonymous, 2010, Degraded and Wastelands of India Status and Spatial Distribution, ICAR publication: 167.

Anonymous, 2017 , https://economictimes.indiatimes. com/ markets/commodities/news/tightglobal-supplies-hit-cashew-industry-inindia/articleshow/58510169.cms (Accessed on 25.06.2018)

Anonymous, 2018 https://www.nutfruit.org/what-wedo/industry/statistics (Accessed on 27.06.2018)

Deckers, J. Cundall, E., Shomari, S. H., Ngatunga, A. and Bassi, G (2001). Cashew (Anacardium occidentale L.). In: Raemaekers, R.H., ed.: Crop Production in Tropical Africa. Directorate General for International Co-operation, Ministry of Foreign Affairs, External Trade and International Co-operation, Brussels, Belgium, 691-700. [Paper describing the control of insect pests of cashew, especially Helopeltis bugs and stem borers].
Estruch, R., E. Ros, M. I. Covas, D. Corella, F. Arós, and E. Gómez-Gracia, 2013, Primary prevention of cardiovascular disease with a Mediterranean diet. $N$. Engl. J. Med. 368:1279-1290.

Fagundes, L. A., 2002, Omega-3 \& Omega-6. Rio Grande de Sul, Brasil: Raven Press: 38.

FAOSTAT, 2017, http://faostat.fao.org. (Accessed on 26.06.18).

Flores-Mateo, G., D. Rojas-Rueda, J. Basora, E. Ros, and J. Salas-Salvadó. 2013. Nut intake and adiposity: meta-analysisof clinical trials. Am. J. Clin. Nutr. 97:1346-1355.

Flores-Mateo, G., David Rojas-Rueda, Josep Basora, Emilio Ros, and Jordi SalasSalvadó, 2013, Nut intake and adiposity: meta-analysis of clinical trials, Am. J. Clin. Nutr.97:1346-55.

Hubballi, V.N., 2018, Cashew developmentEncashing Technological innovations for production and processing of cashew, In: Souvenir of National Conference on Cashew, $12^{\text {th }}$ to $14^{\text {th }}$ Feb. 2018 at Bhubaneswar,Odisha.

Jnanadevan, R., 2018, Indian cashew in global trade- Problems and Prospects, In: Souvenir of National Conference on Cashew, $12^{\text {th }}$ to $14^{\text {th }}$ Feb. 2018 at Bhubaneswar,Odisha.

Kapinga,F.A., Kasuga, L. J. F. and E. M. Kafiriti, 2010, Growth And Production Of Cashew Nut, Soils, Plant Growth And Crop Production - Growth and Production of Cashew Nut: 1-10.

Lowor, S.T. and C.K. Agyente-Badu, 2009. Mineral and Proximate Composition of Cashew Apple (Anarcadium occidentale L.) Juice from Northern Savannah, Forest and Coastal Savannah Regions in Ghana. American Journal of Food Technology, 4: 154- 161

Mah E., Schulz J.A., Kaden V.N., Lawless A.L., Rotor J., Mantilla L.B., Liska D.J., 2017, Cashew Consumption 
Reduces Total and LDL Cholesterol: A Randomized, Crossover, ControlledFeeding Trial. Am. J. Clin. Nutr.: 105:1070-1078.

Rico, R., Bullo, M. and Salvado, J.S., 2017, Nutritional composition of raw fresh cashew (Anacardium occidentale L.) kernels from different origin. Nutrients, 9 (12): 1311.

Rieger, M. (2006). Cashew - Anacardium occidentale. http://www.uga.edu/fruit/
cashew.html].[Information on the origin and distribution of cashew. Description on when the international cashew nut trade started].

Santos Andrade, T.J.A., Araújo, B.Q., Lopes Citó, A.M.G., Juliana da Silva, Jenifer Saffi, Marc François Richter, Falcão Ferraz, A.B., 2011, Antioxidant properties and chemical composition of technical Cashew Nut Shell Liquid (tCNSL). Food Chemistry, 126:10441048.

\section{How to cite this article:}

Bhoomika, H.R. and Sudha Rani, N. 2018. Problems and Prospects of Cashew Cultivation in India - An Overview. Int.J.Curr.Microbiol.App.Sci. 7(10): 3687-3694.

doi: https://doi.org/10.20546/ijcmas.2018.710.426 